Impact Factor: 4.845(SJIF) Research Journal Of English (RJOE) Vol-5, Issue-1, 2020

www.rjoe.org.in An International Peer-Reviewed English Journal

ISSN: 2456-2696

Indexed in: International Citation Indexing (ICI), International Scientific Indexing

(ISI), Directory of Research Journal Indexing (DRJI) Google Scholar \& Cosmos.

\title{
RABINDRANATH TAGORE'S LOVE LYRICS: A FUSION OF THE DEVINE AND THE HUMANE
}

\section{Dr. Reji George \\ Assistant Professor \\ Department of English, Samtah University College, Jazan University, Kingdom of Saudi} Arabia

\begin{abstract}
It is perhaps true to say that no man in the whole range of known history can rival Rabindranath Tagore's all-comprehending genius, equally splendid in thought, in creation and in action. In literature or art, there was no form that he did not touch and there was nothing he touched which he did not adorn. The keynote of Rabindranath Tagore's literature is love - the love that stands the test of time, the love that gives invincible strength to undergo extreme sacrifices. It is the love for man that condemns war and violence in every form. It is the love that transcends the differences of races and colours, castes and creeds. It is the universal cord of love that binds all life in a single knot that is unshakable and unbreakable. It produces an unending rhythm of truth, beauty and bliss. It is love that conquers old age and kills death itself. It is the omnipotent love that transforms a hardened criminal into a saint. The objective of the present study is to bring to light Tagore's inseparable love for God, man and nature and to stimulate the readers to strive for true love where violence and murder has no role to play.
\end{abstract}

Keywords:Fusion of God, nature and man, Devine love, Human love, Love for nature, Eternal love.

\section{Introduction}

Rabindranath's life was long, covering the last forty years of the nineteenth century and the first forty of the twentieth. His creative output, in its great variety, was prolific. Tagore is the voice of the nation's dreams and longings, its sorrows and sufferings, the memories of its past and the visions of its future, its attitudes and its ideals. Love constitutes the major theme in Tagore's lyrical poetry. His love-poems display a great depth of feeling, variety, and form, which rank them as the finest love poems of the world. His poems reveal the pangs and frustrations, trials and tribulations, sorrows and joys of love. Love flows from his heart, mind and soul in continuous stream, assuming all different forms-from the known to the unknown, from the finite to the infinite. He interprets it in all its multiform expressions: 
Impact Factor: 4.845(SJIF) Research Journal Of English (RJOE) Vol-5, Issue-1, 2020

www.rjoe.org.in An International Peer-Reviewed English Journal

ISSN: 2456-2696

Indexed in: International Citation Indexing (ICI), International Scientific Indexing (ISI), Directory of Research Journal Indexing (DRJI) Google Scholar \& Cosmos.

the love of mother, of son, of husband, wife, lover, beloved and friend. He was that rare phenomenon in the world of men - the integrated man with a mind of very wide perception.

Rabindranath Tagore was a versatile genius. He was a poet of so high a caliber that the world hardly came across one such in a millennium. He seems to have adorned Shelley, Wordsworth, Keats, but not Shakespeare to the same extent. Shelley's doctrine of love, Wordsworth's view of nature and Keats's worship of beauty had a profound influence on him. His treatment of love is romantic, warm and humane. He is a superb singer of the various aspects of love. He wrote in Creative Unity, "Peace is true and not conflict, love is true and not hatred."The greatest of Tagore's discoveries is love and his conception of love is beyond measure. He melts into one sweet harmony all that is ugly, hideous, monstrous, depressing and revolting in life. There is no wonder why torture and brutality have hardly a role to play in his creative works. Each of his poems, lyrics, stories, essays, novels, plays and travelogues and even the large number of letters written by him to his friends are highly finished products of a consummate artist belonging to the great Indian heritage.

The theme of Tagore's poetry can be summed up in four letters 'LOVE,' that islove for divinity, love forhumanity and love for nature. His love songs often resort to a little too rarefied air and are interchangeable. The strength and grace of his words lend a special quality to his works which are rare in any country's literature

\section{Love for the divine}

In 'Ananta Prem'of Manasi, Tagore explains, love is eternal and man and God are also eternal. In eternal love finite man is lover and Infinite God as beloved becomes intimate or one, and thus in truth, love makes God human and man Divine. The Infinite manifests itself in the finite where lies the fundamental ideas of truth and beauty. Tagore's poetry is both, a realization and an expression of Truth. He touched nothing which he did not adorn, revealed nothing which he did not experience, and expressed nothing which he did not realize in Truth. W.B. Yeats(2001) comments in his introduction to Gitanjali, every morning at three, 'he sits immovable in contemplation, and for two hours does not awake from his reverie upon the nature of God'. Gitanjali fixed Tagore's image in the western mind irrevocably. He is seen as a mystic basically, a wise man from the East, 'an ineffective dreamer, dignified and calm.'W.B. Yeats (2001)

Commenting on Tagore's love poetry, Humayun Kabir (1966) states that his love for man is unconsciously and inevitably merged into love of God. For him God was essentially love. The love of mother for her child, or the love of the lover for the beloved are only instances of the Supreme love that is God. And this love expresses itself not only in the ecstatic devotion of the mystic but also in the routine of everyday life of the common man. 
Impact Factor: 4.845(SJIF) Research Journal Of English (RJOE) Vol-5, Issue-1, 2020

www.rjoe.org.in An International Peer-Reviewed English Journal

ISSN: 2456-2696

Indexed in: International Citation Indexing (ICI), International Scientific Indexing (ISI), Directory of Research Journal Indexing (DRJI) Google Scholar \& Cosmos.

Tagore's Gitanjali has many aspects and many levels, yet, at root harks back to as Yeats comments: 'We are not moved because of its strangeness, but we have met our own image' Dutta (1995). Tagore's western admirers could see the humane spirit of Christianity venerated in theory but ignored in practice, reflected back at them from Gitanjali in a pure form. Once Harriet Monroe remarked on her experience of sitting around a hearth fire listening to Tagore 'chanting his lyrics' and talking of 'Oriental Creeds,' making her feel as if she was 'sitting at the feet of Buddha.' Dutta (1995). While listening to the translated version of Gitanjali from Yeats,Thomas Sturge Mooreobserved that Tagore's unique and most favoured subject is the love of God. Yeats further added, 'he is absorbed in God.'W.B. Yeats (2001)

In Crossingand Gitanjali Tagore's conception of love assumes spiritual significance.God's relationship to man is essentially a relationship of love- a continual selfgiving in love. Addressing God, Rabindranath says, "Thou givest yourself to me in love" (Gitanjali 65). Right from birth, it is God's love which keeps man alive and takes care of him in God's own home. God's love is of a superior quality than man's and unlike human love, God's love leaves man free:

By all means they try to hold me secure who love me in this

world. But it is otherwise with thy love which is greater than

theirs and thou keepest me free. (Gitanjali 32)

God's love is patient and forgiving. Instead of being quick to condemn, punish or abandon man for his lack of love, waits for a change of heart in man:

If I call not thee in my prayers, if I keep not thee in my heart,

thy love for me still waits for my love. (Gitanjali 32)

God does not despise man's humble activities; rather He comes down to the level of man to join him and walk with him:

Thou didst not turn in contempt from my childish play among

dust, and the steps that I heard in my play room are the same

that are echoing from star to star. (Gitanjali 43)

God's love not only keeps continuous touch with man, it is a love that by repeated contact rouses man to life and action:

HE IT IS the innermost one,

who awakens my being

with his deep hidden touches. (Gitanjali 72)

God in his love keeps coming closer and closer to man, sometimes silently and without man being aware of it, and at other times suddenly and even uninvited. Several times in course of his writing, Tagore has expressed this faith:

I know not from what distant time thou art ever coming nearer

to meet me. (Gitanjali 46) 
Impact Factor: 4.845(SJIF) Research Journal Of English (RJOE) Vol-5, Issue-1, 2020

www.rjoe.org.in An International Peer-Reviewed English Journal

ISSN: 2456-2696

Indexed in: International Citation Indexing (ICI), International Scientific Indexing (ISI), Directory of Research Journal Indexing (DRJI) Google Scholar \& Cosmos.

Rabindranath always had an ardent desire for constant presence and a total union with God. He wishes to enter more deeply into the mystery of the divine and arrive at a more personal and profound understanding of that reality:

Oh, how, indeed, could I tell them that for thee

I wait, and thou hast promised to come(Gitanjali 41)

Asecular and the spiritual mingling is always found in his love lyrics. The secular longing for the lover becomes the spiritual longing of the human soul for complete union with God.

God, for Tagore, is the one infinite centre to which all personalities and all the world of reality are related. He is the one Supreme Person, the one Supreme Reality. Describing the relationship between God and man.Estborn (1949) remarks, "For Tagore, God is the Supreme Lover whose touch we experience in all our relations of love. His love is absolutely unselfish and it leaves man free. God seeks man and waits for man's response." Life is a love-game of hide and seek that goes on between the finite soul and the infinite. Love, Tagore insists, is the perfect personal relationship.

The Supreme Love, in Tagore's conception takes the shape of fatherly love. The name 'father' is central to Tagore's understanding of God. According to him, God's love comes not out of surplus but out of want. Without our love God's love is imperfect. "The infinite became defined in humanity and came close to me so as to need my love and co-operation." Estborn (1949)The God in man depends upon men's service and men's love for his own love's fulfillment. "O Thou Lord of heavens, where would be thy love if I were not?" (Gitanjali 56) It could be assumed that for Tagore, God's love would be nothing without man's love.

\section{Love for man}

Rabindranath Tagore believed in love as a bond between man and man. It transcends beyond life. A man can meet his beloved even in the next life because real love never perishes. Just like the human soul, real love could also be eternal. A few western poets, too, believed in eternal love, 'that hath no beginning, hath no end.' Shelley, for instance, maintained, "there is no death, nor change" Bhattacharya (1987). Rabindranath expressed similar thoughts in innumerable poems and other works.

Tagore's poems on love and nature are highly sensitive and full of passion and life. The lover's agony in his spellbound heart is far an idea rather than a person. This intimacy is of a rare kind, a bodiless love in the end, an eternal confession, of the world's love-lorn. Such type of compassion continues age after age, life after life. In Urvasi, he characterizes the personality of a romantic image of an abstract idea as the myth maiden, who is neither mother, daughter, sister, nor wife.

Tagore is a great love poet with extraordinary subtlety; he analyses the different moods and captures the ardent passion, which lovers feel for each other. There is a great originality and delicacy in the art with which he portrays the ever-shifting moods and emotional intricacies of love. On several occasions he exhibits how love comes in one's life 
Impact Factor: 4.845(SJIF) Research Journal Of English (RJOE) Vol-5, Issue-1, 2020

www.rjoe.org.in An International Peer-Reviewed English Journal

ISSN: 2456-2696

Indexed in: International Citation Indexing (ICI), International Scientific Indexing (ISI), Directory of Research Journal Indexing (DRJI) Google Scholar \& Cosmos.

suddenly, with a strange thrill and overpowers the soul with ecstasy and disorganize them in the daily occupation of their lives. In the Gardener and the Lover's Gift, the yearning of the lovers has been brought out with extraordinary skill. Many of the poems reveal the depth, the agony and the fever of this most fundamental of all human passions. Tagore's Gardeneris a feast of love poetry. Iyengar (1961) comments, "All the make-believe and love play that lovers feed on, all the agony and hopelessness, all the ecstasy and fulfillment of lovers lives, all is woven here into a garland of memorable songs"

His originality as a love poet lies in his ability to use images from the common objects of nature, to express the various shades, and moods of love. His imagery is highly expressive, suggestive and original; it surprises and startles.In one of the poems in the Lover's Gift, the lover's heart is likened to an orchard in which ripe fruits are eager to burst, and hold their sweets to the beloved's lips. Elsewhere, the lover's heart is represented as a lake and the ladylove is invited to fill her pitcher in it. These images are fresh and startling like a metaphysical conceit. But Tagore is never far-fetched in his imagery like Donne and his followers.

His treatment of love is without pangs, without pricking, without frustration and without exaggerated sighs. It is natural and simple, and it is a product of Indian culture.It knows its limits; it does not go beyond an acceptable line. He fashions his beloved as a shy woman who braids her hair, puts on a green mantle and goes alone to her love-tryst. In another picture she milked the cow with hands as tender and fresh as butter. He stood in silence, with his empty can. The bird sang unseen from the thicket; he observed her transfixed. Tagore's love lyrics are an overflow of Indian sensibility. Iyengar (1961) states that the imagery, the conceits, the basic experience, the longing, the trial, the promise, the realization, all have the quaintly unique Indian flavour and taste."

Not only is love a strange, disturbing sensation but it is also an absorbing passion. A good many of the poet's love-lyrics reveal the depth and the agony, the fever and the fret of the lovers. The intensity of love is portrayed through a number of original and telling images. For instance, in his eager desire for union, the lover naturally minimizes the distance between him and his sweetheart, saying that she is as near to him as the meadow flower is to the earth, an image which is as novel as it is suggestive.(Lover's Gift 4)

In some poems, along with the intensity of love, the poet deals with its infinite mystery as well. In The Gardener28, he shows that even when the human heart has wholly surrendered itself, it fails to explain all its significance. Love is too deep for expression, and the ladylove who wants to know her sweet heart perfectly, is like the moon trying to fathom the bottom of the sea. The same idea is expressed in a completely different manner in Lover's Gift23. The lovers are on the two banks of the same river, which beautifully suggests 
Impact Factor: 4.845(SJIF) Research Journal Of English (RJOE) Vol-5, Issue-1, 2020

www.rjoe.org.in An International Peer-Reviewed English Journal

ISSN: 2456-2696

Indexed in: International Citation Indexing (ICI), International Scientific Indexing (ISI), Directory of Research Journal Indexing (DRJI) Google Scholar \& Cosmos.

separation in union. The same river runs between them, singing the same song, but as they hear from opposite banks; there is a difference between the messages it conveys to them.

Rabindranath, not only portrayed the depth, vigour and expansiveness of love but also analyzed its more lighthearted phases. In The Gardener40,the speaker tries to evoke a note of pathos because he is bidding farewell; but the sweetheart knows and so does the speaker himself that he will come back and that the leave-taking is only apretense. But he pleads with her all the while to accept the illusion of farewell; for it will add zest to their lovemaking and if she can shed tears, it will only deepen the dark rim of her eyes and thus add to her beauty.

In some lyrics of love there is a dramatic interpretation of motives. An example of the mixture of mood is seen in The Gardener 33 in which the heroine alternately asks for pity, forgiveness in love to a bird losing its way.Sherealizes that by yielding to the call of love her heart has laid bare it's secret. In this moment of absolute surrender, she wants the lover to cover her with his pity. It is probable that the man to whom she has given herheart may not be able to respondto her advances. In that case, she will cover her forlornness with both her hands. In the next stanza, she changes the possibility of his loving her. Then she will sit on a throne and rule him like a goddess, but even then she realizes that her power will depend on him and her strength will be the strength of weakness.

Tagore's early love poetry is marked by authenticity of personal experience. It reveals his intense love for someone whose identity is shrouded in mystery. The fair creature who intoxicated the young poet's heart with beauty and passionate love might be Nalini, the young Maharastrain girl whom the poet loved, or she might be Kadambari, his sister-in-law who inspired him to write and whom he adored. In Kada O Kamaland Manasihis lyrics echo his personal unfulfilled longings, frustration and he conjures up vivid romantic images to visualize his beloved whose beauty is beyond all description.Hedescribes graphically the romantic meeting of two young lovers:

Do not go, my love, without asking my leave.

I have watched all night,

and now my eyes are heaving with sleep.

I fear lest I lose you when

I am sleeping.

Do not go, my love, without asking my leave. (The Gardener, 34)

Kada O Kamal and Manasiexpress his personal love on a real physical plane. It thrilled the lovers of poetry, as it was something new in Indian literature.

I CLASP YOUR hands, and my heart plunges into the dark of your eyes,seeking you, whoever evade me behind words and silence. (Lover's Gift, 25) 
Impact Factor: 4.845(SJIF) Research Journal Of English (RJOE) Vol-5, Issue-1, 2020

www.rjoe.org.in An International Peer-Reviewed English Journal

ISSN: 2456-2696

Indexed in: International Citation Indexing (ICI), International Scientific Indexing (ISI), Directory of Research Journal Indexing (DRJI) Google Scholar \& Cosmos.

These lines match for their exquisite lyricism, reveal the passion and intensity of lovers. Tagore shows high esteem to woman. She is not only beloved but also harbinger of beauty and order in man's life. He writes in Fruit Gathering:

Bring beauty and order into thy forlorn life, woman, as you brought into my house when you lived.

Sweep away the dusty fragments of hours, fill the empty jars, and mend all that has been neglected.

Then open the inner door of the shrine, light the candle, and let us meet there in silence before our God.

Rabindranath believes that woman's love is the noblest of all life's gifts. He is convinced that it possible to realize the Infinite through love. He wrote the play Sanyasiorthe Asceticon this theme. The Sanyasi who prided himself upon renunciation, and thought of the world as darkness or emptiness, comes across a girl and finds that the world is worthwhile to live in and that love is a reality. He says, "The finite is the true infinite and love knows its truth" Tengshe (1961). Tagore used the word 'love' in its widest and noblest sense. He is ecstatic when he talks of motherhood and affirm that the altar at which woman may be truly worshipped is her place as mother, the seat of the pure, right-minded Lady of the house.Tengshe (1961)

Rabindranath kept the sacred lamp of worship kindled in his heart for the worthy women with whom he came in contact. While speaking of them, he said, "Sometimes such a bright picture of a woman flashed upon my eyes who cannot be termed as modern but who belonged to all times. Whenever we committed a fault in our conduct we saw light of forgiveness in their eyes. They lighted the lamp of love from the fire of Virtue" (Ghose 98). Women's nobility lies in her ability to forgive the fault of others with a smile.

Tagore once said that the greatest treasure of a woman is not her body but her mind. He wrote: "O beautiful one, what are you looking at in your mirror? Are you trying to find if there is any blemish in the offering of love which you are going to give to the dear one?" Ghose (1987). Tagore's treatment of love is very warm and human, and he mustbe ranked with the greatest love poets of the world despite his mysticism and the large bulk of his devotional poetry. In his Urvasiwe get a picture of a perfectly beautiful woman, whom poets have dreamed of, but few have succeeded in giving their dreams such a sensuous and perfect expression. She is the nectar of beauty in the sparkling bowl of eternal youth. Passion here shoots out like a flame only to smolder in a glow.

Love for Nature Tagore regardsnature as a vast storehouse of images, similes and metaphors.Every day commonplace objects and phenomena are constantly drawn upon by 
Impact Factor: 4.845(SJIF) Research Journal Of English (RJOE) Vol-5, Issue-1, 2020

www.rjoe.org.in An International Peer-Reviewed English Journal

ISSN: 2456-2696

Indexed in: International Citation Indexing (ICI), International Scientific Indexing (ISI), Directory of Research Journal Indexing (DRJI) Google Scholar \& Cosmos.

him to communicate highly abstract religious truths. There is a surprising demonstration of the abundance of nature imagery in his lyrics. No poet ever lived, has a more constant and intimate touch with natural beauty as Tagore. He can use at his best, the same images and pictures, the oldest ones in the world, a score of times in as many lines, and each time with freshness and charm. His wealth of knowledge and creativity is inexhaustible, and it is manifest in prose as in verse, in English as in Bengali. The flowers, the rivers, the stars, the sun and the moon, the lightning, and a host of other objects and phenomena are all pressed by him into service. His nature imagery is visual graphic and pictorial. In this respect, he remains unsurpassed and unmatched.

Everyone who has the slightest acquaintance with Tagore's poetry will know how dominant a place nature occupies in them. In almost every page of his poetry, we come across his delight in this 'sun-kissed world' and all that is in it: its dark forests, streams, torrents and lakes, pattering rain, moonlit nights, multifarious forms of life, the green trees and smiling flowers, the cattle grazing on the slope by the river, the children merrily singing and dancing in the grove.

I have kissed this world with my eyes and my limbs; I have wrapped it within my heart in numberless folds; I have flooded its days and nights with thoughts till the world and my life have grown one, - and I love my life because I love the light of the sky so enwoven withme.(Fruit Gathering, 53)

Tagore's intense love for nature, was apparently innate in him and came to light very early. In Reminiscences he tells of the inner garden of the Tagore house, 'Jorasanko,' in Kolkata, a garden which was poor enough, consisting only of a citron tree, a couple of plum trees and a row of coconut trees. Nonetheless, this 'Jorasanko' garden was a paradise to little Rabindranath, the adornment of which could well match that of Adam's Garden of Eden.

At the age of twelve, Tagore visited Santiniketan for the first time, in the company of his father. Arriving at Bolpur in the evening, he closed his eyes, when he got into the palanquin which was to take him from the railway station to the ashram; for he wanted to preserve the whole of the wonderful scenery to be unfolded before his waking eyes in the morning light.He feared that the freshness of the experience would be spoilt by incomplete glimpse caught in the vagueness of the evening dusk (Reminiscences 18).

Nature exercised a great influence in shaping Tagore as a poet. From his very boyhood he enjoyed the beauties and glories of Nature. As a teenager he looked at the earth and the sky, the sun and the moon, the stars and the mystery of nocturnal sky, the trees and the hills, the birds and the flowers, the day and the night with a feeling of wonder and mystery. Nature appealed to him as it appealed to Wordsworth.He writes about his intimate union with nature: 
Impact Factor: 4.845(SJIF) Research Journal Of English (RJOE) Vol-5, Issue-1, 2020

www.rjoe.org.in An International Peer-Reviewed English Journal

ISSN: 2456-2696

Indexed in: International Citation Indexing (ICI), International Scientific Indexing (ISI), Directory of Research Journal Indexing (DRJI) Google Scholar \& Cosmos.

I had a deep sense, almost from infancy of the beauty of nature and intimate feeling of companionship with the trees and the clouds, and felt in tune with musical touch of the seasons in the air. At the same time, I had a peculiar susceptibility to human kindness. (Lectures and Addresses)

As he grew up, all these carved expressions weregiven his own utterances in lyrics of boundless beauty and sweetness. Rabindranath Tagore was a versatile genius. He was a poet of high excellence that the world hardly came upon one such in a millennium. Tagore was a worshipper of nature and beauty, having the closest tie with both these elements and he virtually lived and breathed in them. Nature has drawn him intensely towards universality. He sings:

Take me back, O Mother Earth,

Take your child into your arms.

In the folds of your vast protecting garments

O Mother Earth,

Let me expand in your soil,

Scattering myself in endless directions

Like the joy of Spring. (Collected Poems and Plays)

It is to be noted that Nature in Tagore's love poetry is not merely decorative; she is represented as sympathetic to the mood of the lovers. Time and again she takes on their frame of mind and is identified with them. Nature is humanized and it reflects the joys and sorrows of lovers, and thus human affection and anguish are intensified. When the lovers meet, their joy find its expression in the delight of nature, and the mother earth dances with jubilation. When they are separated, nature reflects their suffering. Sometimes the sentiments of love especially its sorrows, supply the poet with food for reflection on the facts of life and death, and the treatment of love with his philosophy of life. M.K. Naik (1982) believes that Tagore's love poetry seems to have been influenced by Browning. Tagore exhibits a Browningesque variety and complexity in his love poetry, though his setting, unlike that of the British poet, is invariably rural and feudal. Like Browning, Tagore too is capable of both the subjective and objective approaches, and can offer both a direct outpouring of emotion, of which the very first piece in The Gardener, 62 (The Dialoguebetween the Servant and the Queen) is a fine example.

\section{Conclusion}

Tagore vividly describes almost all the aspects of love in lyrics of unsurpassable beauty. The human and the spiritual have been blended together in his 
Impact Factor: 4.845(SJIF) Research Journal Of English (RJOE) Vol-5, Issue-1, 2020

www.rjoe.org.in An International Peer-Reviewed English Journal

ISSN: 2456-2696

Indexed in: International Citation Indexing (ICI), International Scientific Indexing (ISI), Directory of Research Journal Indexing (DRJI) Google Scholar \& Cosmos.

love lyrics, and in this respect he is without a parallel in Indian English poetry. The fusion of God, nature and man is a recurrent theme in his poetry. Nature is the abode of God; the various aspects of nature are symbols of eternity. He spiritualizes human love and humanizes spiritual love. The greatest of Tagore's discoveries is love and his conception of love is beyond measure. He melts into one sweet harmony-the harmony of love all that is ugly, hideous, monstrous, depressing and revolting in life. Each of his poems, lyrics, stories, essays, novels, plays and travelogues and even the large number of letters written by him to his friends are highly finished products of an exemplary artist belonging to the great Indian heritage.God dwells in his own creation, and it is expected of man that he also must create his environment, his own dwellingplace, which should be worthy of his soul.

References

- Bhattacharya, V.R. Tagore's Vision of a Global Family.New Delhi: Enkay Publishers, 1987.

- Dutta, K., Robinson, A. Rabindranath Tagore: The Myriad Minded-Man.London: Bloomsbury, 1995.

- Estborn, S. The Religion of Tagore in the Light of the Gospel. Madras: The Christian Literature Society for India, 1949.

- Ghose, Sookamal The Centenary Book of Tagore. New Delhi: Sahitya Akademi, 1987.

- Iyengar, S.K.R. Indian Writing in English. Bombay: Vora and Co. Publisher, 1961.

- Kabir, Humayun. Introduction to One Hundred One. New Delhi: Publishing House, 1966.

- Naik, M.K. History of Indian English Literature.New Delhi: Sahitya Akademi, 1982.

- Radhakrishna, S. East and West in Religion George Allen Unwin, 1954.

- Saha, Panchanan. Tagore and Gandhi; Confluence of Mind_Kolkata: Barasat Barta, 2001.

- Tagore, Rabindranath. Reminiscences. London: Macmillan, 1977.

- ---. Collected Poems and Plays. London: Macmillan Papermac Edition, 1989.

- ---.Fruit Gathering. London: Macmillan, 1916.

- ---.Introduction to Creative Unity. London: Macmillan, 1939.

- ---.Lectures and Addresses. London: Macmillan, 1970.

- ---.Lover's Gift and Crossing. Chennai: Macmillan India, 1980.

- ---.Manasi and Other Stories.London: Macmillan, 1918.

- ---.The Gardner.Chennai: Macmillan Pocket Edition, 1988. 
Impact Factor: 4.845(SJIF) Research Journal Of English (RJOE) Vol-5, Issue-1, 2020

www.rioe.org.in An International Peer-Reviewed English Journal ISSN: 2456-2696

Indexed in: International Citation Indexing (ICI), International Scientific Indexing (ISI), Directory of Research Journal Indexing (DRJI) Google Scholar \& Cosmos.

- Tengshe, L.H. Tagore and His Views of Art. New Delhi: Vora and Co. Publisher 1961.

- Thomas, Edward. Tagore:His Life and Work.London Association Press, 1928.

- Yeats, W.B. Introduction to Gitanjali. Delhi: Macmillan India Ltd, 2001. 